\title{
The Need for Reform of Ex-Felon
}

\section{Disenfranchisement Laws}

The Supreme Court has recently granted certiorari ${ }^{1}$ to review the decision of the California Supreme Court in Ramires $v$. Brown," which held the California constitutional and statutory provisions ${ }^{3}$ disenfranchising ex-felons invalid as violations of the equal protec-

1. Sub nom. Richardson v. Ramires, $94 \mathrm{~S}$. Ct. 45 (1973). The state of California subsequently filed a petition for a writ of certiorari in the same case, California $v$. Ramires, 42 U.S.L.W. 3125 (U.S. Sept. 11, 1973). The Court has also docketed a district court decision upholding Washington's ex-felon disenfranchisement law, Dillenburg v. Kramer, Civil No. 9725 (W.D. Wash. May 22, 1973), appeal docketed, 42 U.S.L.W. 3164 (U.S. Sept. 17, 1973).

This term the Supreme Court will also hear an appeal from a decision denying detainees the right to receive absentee ballots. O'Brien v. Skinner, 31 N.X.2d 317, 291 N.E.2d 134, 338 N.Y.S.2d 890 (1972), prob. juris. noted, 411 U.S. 963 (1973). This may result in some consideration of the question of felon disenfranchisement. This Note, however, addresses the question of disenfranchisement of ex-felons, that is, those felons who have completed their prison sentences. Exclusion of prisoners from the franchise is apparently regarded as part of the general loss of liberty suffered by prisoners. See Jackson v. Bishop, 404 F.2d 571, 576 (8th Cir. 1968) (dicta by Blackmun, J.); cf. McDonald v. Board of Election Comm'rs, 394 U.S. 802 (1969); Project, Collateral Consequences of a Criminal Conviction, 23 VAND. L. REv. 929, 950-51, 977-80 (1970) [hereinafter cited as VANDERBILT Project]. Disenfranchisement of felons who have been released from prison but who are still on probation or parole presents problems similar to disenfranchisement of ex-felons whose sentences have expired completely. Although a parolee or probationer has certain restrictions placed on his liberty, see note 66 infra, his situation seems closer to the ex-felon than to the prisoner. See p. 592 infra. The California Supreme Court in Ramires specifically limited its decision to ex-felons whose terms of incarceration and parole had expired. See 9 Cal. 2d 199, 507 P.2d 1345, 107 Cal. Rptr. 137 (1973). Most suits challenging the disenfranchisement laws have been brought by plaintiffs whose prison terms and parole had expired, and the decisions seem limited to those facts. See, e.g., Dillenburg v. Kramer, 469 F.2d 1222 (9th Cir. 1972); Fincher v. Scott, 352 F. Supp. 117 (M.D.N.C. 1972), aff'd mem., 411 U.S. 961 (1973); Beacham v. Braterman, 300 F. Supp. 182 (S.D. Fla.), aff'd mem., 396 U.S. 12 (1969). The relevant inquiry would seem to be whether the loss of liberty while on parole can include disenfranchisement; $c f$. Sobell v. Reed, 327 F. Supp. 1294, 1303 (S.D.N.Y. 1971).

2. 9 Cal. 3d 199, 507 P.2d 1345, 107 Cal. Rptr. 137 (1973).

3. The California constitution provides that "Laws shall be made to exclude from office, serving on juries, and from the right of suffrage, persons convicted of bribery, perjury, forgery, malfeasance in office, or other high crimes." CAL. CoNsT. art. 20, $\$ 11$. A voter is required to provide an affidavit saying that he is not disqualified by reason of a felony conviction, but the code states that not all felony convictions cause disqualification. Cal. Elections Code $\$ 310$ (West Supp. 1973). The qualifying clause is the result of Otsuka v. Hite, 64 Cal. 2d 596, 414 P.2d 412, 51 Cal. Rptr. 284 (1966), in which the state supreme court, in order to find the law constitutional, construed it as excluding only those ex-felons guilty of offenses which indicated a propensity to commit election crimes. Application of this rule was left to local authorities. The result of this delegation was that the offenses for which an ex-felon could be disenfranchised varied greatly from county to county. Some counties rarely disenfranchised; others disenfranchised for practically all crimes. Some included narcotic offenses; others did not. Some counties distinguished between rape and statutory rape, the former causing disenfranchisement and the latter not. See California Secretary of State, Report Regarding the Right to Vote of Ex-felons, May 30, 1972.

Ramires overruled Otsuka, finding the narrow construction of the law insufficient to save it, and held it unconstitutional as applied to ex-felons whose sentences and parole had ended. 
tion clause of the Fourteenth Amendment. While there have been a number of lower court decisions on this subject, ${ }^{4}$ as well as summary decisions ${ }^{\mathbb{T}}$ and dicta from the Supreme Court, ${ }^{6}$ this should provide the first full Supreme Court consideration of the question.

For the past 80 years the leading case on ex-felon disenfranchisement has been Davis $v$. Beason, ${ }^{7}$ which upheld a territorial law excluding bigamists or members of organizations advocating bigamy. ${ }^{8}$ The only constitutional issue raised in that case, however, was a First Amendment free exercise of religion question. Furthermore, the Court relied on arguments which are in direct conflict with modern equal protection doctrine. ${ }^{9}$

4. E.g., Dillenburg v. Kramer, 469 F.2d 1222 (9th Cir. 1972); Green v. Board of Elections, 380 F.2d 445 (2d Cir. 1967), cert. denied, 389 U.S. 1048 (1968); Kronlund v. Honstein, 327 F. Supp. 71 (N.D. Ga. 1971); Stephens v. Yeomans, 327 F. Supp. 1182 (D.N.J. 1970). See also Cody v. United States, 460 F.2d 34 (2d Cir. 1972); Zwich v. Freeman, 373 F.2d 110 (2d Cir. J967) (deprivation of civil liberties upheld against several challenges); Morrison v. California, 238 F. Supp. 22 (S.D. Cal. 1964) (challenge to system of depriving felons of both political and civil rights upheld). Loss of civil rights presents an analogous situation to disenfranchisement, but there are significant differences because of the specially protected position of voting rights. See pp. 588.89 infra.

5. E.g., Fincher v. Scott, 411 U.S. 931 (1973), aff'g mem., 352 F. Supp. 117 (M.D. N.C. 1972); Beacham v. Braterman, 396 U.S. 12, aff'g mem., 300 F. Supp. 182 (S.D. Fla. 1969).

6. See, e.g., Harper v. Virginia State Bd. of Elections, 383 U.S. 663, 673 (1966) (Black, J., dissenting); Gray v. Sanders, 372 U.S. 368, 380 (1964); Lassiter v. Northampton County Bd. of Elections, 360 U.S. 45 (1959); Trop v. Dulles, 356 U.S. 86, $96-97$ (1958); Estep v. United States, 327 U.S. 114, 122 n.13 (1946).

These dicta have assumed the constitutionality of ex-felon disenfranchisement without actually considering the constitutional problems involved. Judge Friendly, in Green v. Board of Elections, 380 F.2d 445, 451 (2d Cir. 1967), cert. denied, 389 U.S. 104 (1968), however, argued that the frequency of references to ex-felon disenfranchisement by the Supreme Court makes them more than "unconsidered dicta." On the other hand, the source of all these dicta is the easily discredited case of Davis v. Beason, 133 U.S. 333 (1890), see notes 7-9 infra, a fact suggesting that the question of felon disenfranchisement may still be "unconsidered" for present purposes.

7. 133 U.S. 333 (1890). The Idaho constitutional provision challenged in Davis v. Beason is still in effect today. IDAнo CoNST. art. $6, \$ 3$. It excludes from the franchise bigamists, advocates of bigamy, and members of organizations advocating bigamy. No conviction for violation of laws against bigamy is required to cause disenfranchisement. Thus as long as the Mormon church advocated bigamy, all of its members were automatically deprived of the vote whether or not they practiced or advocated bigamy themselves. The Court did not comment on this, treating the law as one disenfranchising criminal offenders.

8. The earlier case of Murphy v. Ramsey, 114 U.S. 15 (1885), upheld a federal statute disenfranchising bigamists against the argument that it was an ex post facto law.

9. Justice Field in his final peroration defended the statute as an attempt to "prevent persons from being enablcd by their votes to defeat the criminal laws of the country." 133 U.S. at 348. The Supreme Court has more recently held, however, that groups of voters may not be "fenced out" because they would vote differently or have different interests than the majority, Cipriano v. City of Houma, 395 U.S. 70I (1969); Carrington v. Rash, 380 U.S. 89, 94 (1965). There is no rational difference between "fencing out" non-property owners from a bond referendum because they might vote for higher taxes (Cipriano) and excluding Mormons because they might vote to legalize bigamy. Even more blatantly in conflict with modern voting rights doctrine is the statement from Murphy v. Ramsey, cited approvingly by Justice Field, that monogamy is the "best guarantee of that reverent morality which is the source of all beneficient progress" and that it is therefore proper for a state to "withdraw all political in- 
In recent years the Supreme Court has twice affirmed lower court rulings upholding ex-felon disenfranchisement laws. ${ }^{10}$ It has done so, however, only in memorandum decisions in cases within its obligatory appellate jurisdiction ${ }^{11}$ with no reasons or authority cited and the effect of these summary affirmances remains opaque. ${ }^{12}$ Ramires, therefore, may provide an authoritative ruling on this increasingly controversial issue.

The various state laws on ex-felon disenfranchisement show more variety than uniformity, and the original legislative purposes are consequently difficult to divine. Three states (Maine, Arkansas, and

fluence from those who are practically hostile to its attainment." 133 U.S. at 315. This reflects a casual attitude towards ballot rights which is inconsistent with modern decisions which treat the right to vote as a "fundamental right" of state citizenship. See pp. 588-89 infra.

10. Fincher v. Scott, 352 F. Supp. 117 (M.D.N.C. 1972), aff'd mem., 411 U.S. 961 (1973); Beacham v. Braterman, 300 F. Supp. 182 (S.D. Fla.), aff'd mem., 396 U.S. 12 (1969). The constitutional arguments discussed in the lower court opinion in Fincher v. Scott, supra, are considered in note 46 infra. The scope of the lower court opinion in Beacham v. Braterman, supra, was much narrower. The opinion stated that felon disenfranchisement was constitutional but mentioned no specific constitutional arguments either supporting or challenging that position. The opinion merely cited Davis $v$. Beason, 133 U.S. 333 (1890), dicta in other Supreme Court cases, and the Second Circuit decision in Green v. Board of Elections, 380 F.2d 445 (2d Cir. 1967), cert. denied, 389 U.S. 1048 (1968). The only issues treated in detail were the equal protection and due process problems arising from the discretion of the governor under Florida law to pardon convicted felons. This is certainly not sufficient to foreclose further consideration of the basic issue.

Furthermore, the California statute involved in Ramires is distinguishable from the North Carolina and Florida statutes involved in Fincher v. Scott and Beacham v. Braterman. The California law is unique in that it requires a determination at the local level that the person excluded has been convicted of an offense which by its nature indicates that the offender is a threat to the electoral system. See note 3 supra. The possibilities for arbitrary enforcement and irrational differences among the policies of local jurisdictions found to exist in Ramires may present constitutional problems which would not arise in a system enforced differently. See p. 592 infra. Also, the California courts have explicitly construed the state law to exclude only those who are likely to abuse the ballot, Otsuka v. Hite, 64 Cal. 2d 596, 414 P.2d 412, 51 Cal. Rptr. 281 (1966). If this determination is accepted, it would rule out any possible justifications based on punitive purposes which might have been raised in defense of the law.

11. See 28 U.S.C. $\$ 1253(1970)$.

12. While summary affirmance is an adjudication on the merits, it does not conclusively resolve the issue when other full Supreme Court decisions by strong implication require a different result; $c f$. Dillenberg v. Kramer, 469 F.2d 1222, 1225 (9th Cir. 1972). On the precedential value of summary affirmances, see generally sources cited United States $c x$ rel. Epton v. Nenna, 318 F. Supp. 899, 906 n.8 (S.D.N.Y. 1970); Study Groul on The Caseload of The Supreme Court, RePort 26 (1972); R. SiERN \& E. Gressmen, Supreme Court Practice 195-96 (1962); Currie, The Three Judge District Court in Constitutional Litigation, 32 U. CH. L. REv. I, 74 n.365 (1964); Frankfurter \& Landis, The Business of the Supreme Court at October Term, 1929, 44 HARv. L. REv. 1, 14 (1930); $c f$. the treatment of a summary affirmance in Vlandis $v$. Kline, 412 U.S. 441 (1973). But see United States ex rel. Fein v. Deegan, 410 F.2d 13, 22 (2d Cir.), cert. denied, 395 U.S. 935 (1969). Even if a lower court might be bound by a summary affirmance, it is difficult to see how the Supreme Court would consider itself bound by a prior affirmance without opinion as it defines the contours of expanding constitutional doctrine. 
Tennessee) have no ex-felon exclusion laws of any sort. ${ }^{13}$ Another ten states exclude ex-felons from voting until the end of the maximum possible sentence allowed by law, until the completion of parole or probation, or during imprisonment. ${ }^{14}$ Three states disenfranchise for a limited period of time, ${ }^{15}$ and several states have significantly liberalized the pardon process. ${ }^{16}$ Five states disenfranchise only those convicted of treason, bribery, or election crimes. ${ }^{17}$ Twenty-eight states disenfranchise virtually all unpardoned ex-felons, ${ }^{18}$ but those states apply many different standards for determining what offenses cause loss of political rights. ${ }^{19}$ California, until Ramires, occupied

13. ARk. Stat. ANN. \$ 3-101 (1947), \$ 3-707 (Supp. 1969); Tenn. Code ANN. \$ 2-205 (1972). Both states have recently repealed restrictive statutes. Note, Disenfranchisement of Ex-Felons: A Reassessment, 25 STAN. L. REv. 845,859 n.106 (1973). Maine has no ex-felon exclusion provisions anywhere in its statutes, see ME. REv. Stat. ANN. tit. 21, $\$ 245$ (Supp. 1972) (setting out requirements for voting).

14. Colo. Const. art. vii, $\$ 10$; Ill. ANn. Stat. ch. 46, $\$ 3-5$ (Smith-Hurd 1973); IND. ANN. STAT. $\$ 29-4804$ (1969); Kan. Stat. ANN. $\$ 62.2252$ (1964); Mich. Const. art. 2, \$ 12; Mich. Comp. Laws ANn. \$ 168.10; Mont. Rev. Codes ANn. \$ 23-2701 (1971); N.Y. Elections LAw $\$ 152$ (McKinney Supp. 1972); ORE. REv. Stat. $\$ 144.320$ (1953); W. VA. Const. art. IV, $\$ 1$; Wis. STAT. ANN. $\$ \$ 6.03(1)$, 57.078 (Supp. 1973).

15. Mo. ANN. STAT. $\$ \S 11.060,216.355$ (1966) (first offenders' rights restored automatically after two years from discharge); PA. CoNsr. art. VII (1968) (only election law offenders excluded; exclusion for that election only); VT. Srat. ANN. tit. 17, 145 (1968) (five year exclusion for election crimes).

16. Conn. Gen. Stat. Rev. $\$ 9-47$ to -48 (1963); N.H. Const. pt. 1, art. 11. Some other states allow the courts to restore all political and civil rights, e.g., CaL. PEnaL CODE $\$ 1203.4$ (West Supp. 1973). The California procedure is apparently little used, as the California Supreme Court in Ramires did not even mention it.

17. Mass. ANn. Laws ch. 51, \& 1 (Supp. 1972); N.H. Const. pt. 1, art. 11; PA. Const. art. VII; VT. Stat. ANN. tit. I7, \$145 (1968); Utah Const. art. IV, § 6. New Jersey, N.J. STAT. ANN. \$ 19:4-1 (Supp. 1972), excludes election law offenders permanently, and all other criminals during imprisonment or parole only.

18. AlA. Const. art. 3, $\$ 182$; AlA. Code tit. 17, $\$ 15$ (1958); Alaska Const. art. 5, \$ 2; Alaska Stat. \$ 15.05 .030 (1971); ARIz. Const. art. 7, \$ 2; Ariz. Rev. Stat. AnN. $\$ 16-101(5)$ (Supp. 1972); DeL. CoNst. art. 5, \$ 2; Fla. Const, art. 6, \$ 4; Fla. STAT. ANN. 97.041 (Supp. 1973); GA. CoNst. \$ 2-801; HawaIr Const. art. 2, \$2; IDAHo Const. art. 6. § 3; IdAho Code \$ 34-402 (Supp. 1972); Iowa Const. art. 2, §5; Ky. Const. \$ 145; LA. Const. art. 8, § 6; LA. Rev. STAT. ANN. \$ 15:572.1 (Supp. 1973); MD. Const. art. 1, $\$ 2$; Md. ANN. Code art. 33, $\$ 3.4(\mathrm{~b})(5)$ (1971); MinN. Const. art. 7, $\$ 2$; Miss. Const. art. 12, \$ 241; MIss. Code ANN. \$ 23-5.35 (1972); Neb. Rev. STAT. \$§ 29-112 to -113 (1964); Nev. Const. art. 2, \$ 1; N.M. Const. art. 7, \$ 1; N.M. STAT. ANN. \$ 3-1-4 (1953); N.C. CoNST. art. VI, \$ 2(3); N.C. GEN. STAT. \$163-55(3) (1972); N.D. Const. art. 5, \$ 12.7; N.D. CENT. CODE $\$ 16.01-04$ (Supp. 1971); OHIo Const. art. 5, \$ 4; OHIo REv. Code ANN. \$\$ 2961.01-02 (Page 1954); OKLA. Const. art. 3, \$11; OKLA. Stat. Ann. tit. 26, $\$ 93.1$ (Supp. 1972); R.I. ConsT. amend. XXIV; S.C. Const. art. 2, \$ 7 (Supp. 1971); S.C. Code ANn. $\$ 23-62(5)$ (c) (Supp. 1971); S.D. Const. art. 7, \$ 8; S.D. Compiled LawS ANn. \$ 12-3-1 (Supp. 1972); TEx. Const. art. 16, \$ 2; Tex. Election Code ANN. art. 5.01 (1967); VA. CONST. art. 2, \$2; VA. CODE ANN. \$24.1-42 (1971); WASH. REv. Code ANN. $\$ 29.07 .070$ (Supp. 1972); WYo. STat. ANs. $\$ 6.4$ (1957). In addition, Missouri permanently excludes all repeating offenders, Mo. ANN. STAT, $\$ \$ 111.060,216.355$ (1966).

19. Most, but not all, of these states use the general term "felon." Some states exclude instead those convicted of "infamous crimes," e.g., WASH. Const. art. 2, $\$ 5$; W.Ash. REv. ConE ANN. $\$ 29.07 .070$ (Supp. 1972); R.I. Const, amend. XXIV; Iowa ConsT. art. 2, $\$ 5$, which can be defined as crimes "infamous at common law" (Rhode Island) or as crimes carrying a penitentiary sentence (Iowa). See VANDERBILT ProJEcT, supra note 1, at 957-59. The penitentiary test is the same as that generally used to define "felony." Some states have a "serious crime" standard, combined either with the "infamous crime" standard, e.g., MD. ANN. CoDE art. 33, $\$ 3.4(\mathrm{~b})(5)(1971)$, or with a list 
an intermediate position. The state constitution and statute ${ }^{20}$ excluded all those convicted of "high crimes" or "felonies," terms which were interpreted by the state supreme court to disenfranchise only those who were convicted of crimes indicating that the offender would be a threat to the election system. ${ }^{21}$

In most states this policy of excluding ex-felons has been almost unquestioned since the early nineteenth century, 22 when voting was regarded as a "privilege" to be exercised only by an elite (white, male, propertied, and of high moral qualities). ${ }^{23}$ The old Supreme Court case, Davis $v$. Beason, ${ }^{24}$ suggests that disenfranchisement is necessary to prevent criminals from voting for repeal of the criminal laws. ${ }^{25}$ Disenfranchisement has often been justified in nebulous terms as an attempt to "protect the purity of the ballot box" against corruption. 26 It might also be viewed as part of the voter qualification system, comparable to the exclusion of aliens, children, the insane, ${ }^{27}$

of specific offenses, e.g., S.C. ConE ANN. \$ 23-62(5)(c) (Supp. 1971). Kentucky bars those convicted of felonies, bribery in elections, or "high misdemeanors" designated by the legislature, Kr. CoNSr. $\$ 145$. Some states exclude only those sentenced to state penitentiaries, e.g., Neb. Rev. Stat. $\$ \$ 29-112$ to -113 (1964). Many states provide lists of offenses (generally not exclusive of other crimes), which range from murder, robbery, and other felonies to such crimes as fornication, bigamy, or encouragement of bigamy, ID.нo Consr. art. $6, \S 3$, incest, miscegenation, sodomy, or vagiancy, $\lambda$. 1 . CodE tit. 17, § 15 (1959), and "any crime involving moral turpitude," AL.iska CoNsr. art. 5, $\$ 2 ;$ Alaska Stat. $\$ 15.05 .030$ (1971). See generally VANDERdLt Project 959-60. Two southern states (MISs. Code AN. \$ 23-5-35 (1972); S.C. Code A.N. \$ 23-62(5)(8) (Supp. 1971)), had long disenfranchised those convicted of sexual crimes and crimes against property, but did not add murder until the 1960's. See generally Ratliff v. Beale, 74 Miss. 247, 266-67, 20 So. 865, 868 (1896).

Many states explicitly include election law violations in addition to felonics or "infamous crimes." Most of the states with specific provisions covering the subject deny the vote to those convicted by the federal government or other states of crimes which cause loss of rights in the home state, Note, supra note 13, at $857 \mathrm{nn} .9496$; Anno., 39 A.L.R.3d 303 (1971), but at least one state, OHio REv. CoDE ANN. \$\$ 2961.01-02 (Page 1954), explicitly excludes federal convicts from those who are disenfranchised.

20. Cal. Const. art. 20, §11; Cal. Elections Code $\S 310$ (West Supp. 1973). See note 3 supra.

21. See Otsuka v. Hite, 64 Cal. 2d 596, 414 P.2d 412, 51 Cal. Rptr. 284 (1966); note 3 supra.

22. Cf. Green v. Board of Elections, 380 F.2d 445, 450 (2d Cir. 1967), cert. denied, 389 U.S. 1048 (1968). See sources cited note 86 infra.

23. See Anderson v. Baker, 23 Md. 531, 575-90, 596-600, 614-19, 622-29 (1865); S. Morrison, H. Commager \& W. Leuchtenburc, The Growth of the Americin Republic 133, 211-14 (1969).

24. 133 U.S. $333(1890)$.

25. This has been echoed by Judge Friendly in his assertion that the equal protection clause could not conceivably require a state to let "convicted mafiosi vote for district attorneys or judges," Green v. Board of Elections, 380 F.2d 445, 451-52 (2d Cir. 1967). See cases cited note 39 infra.

26. Washington v. State, 75 Ala. 582, 585, 51 Am. R. 479, 481 (1884). See State ex rel. Att'y General v. Irby, 190 Ark. 786, 795-96, 81 S.W.2d 419, 423 (1935); Application of Palmer, 61 A.2d 922, 923 (N.J. County Ct. 1948); sources cited VANDERdiLT ProJeCr, supra note 1, at 982 n.298. See also Stephens v. Yeomans, 327 F. Supp. 1182, 1188 (D. N.J. 1970).

27. E.g., Mass. Ann. Laws ch. 51, § I (Supp. 1972); Md. AnN. Code art. 33, § 3.4 (1971). See Kronlund v. Honstein, 327 F. Supp. 71, 73 (N.D. Ga. 1971); cf. cases cited note 39 infra. 
and, until recently, the illiterate. Another purpose may be to punish the ex-felon. ${ }^{2 s}$ Perhaps the purpose of the laws is a mixture of all of these. If pressed to defend the existence of the laws today, most people, perhaps even some legislators, would probably express a feeling that ex-felons are "unworthy" to be voters, an attitude which seems to contain equal elements of punishment of the unworthy and protection of the ballot against the unworthy. ${ }^{29}$ It may consequently be a futile endeavor to try to isolate any one of these goals as the sole purpose of ex-felon disenfranchisement laws.

If the purpose of the laws is regulatory and not punitive, there are certain goals which such regulations may not pursue..$^{30} \mathrm{~A}$ state may not try to secure uniformity of opinion by limiting the franchise to those who share a common interest in the issues being voted upon. ${ }^{31}$ A group cannot be excluded because it might vote differently from the majority, ${ }^{32}$ or because it might "take over" the government or try to control its policy. ${ }^{33}$ It is not at all clear that the ex-felon disenfranchisement laws are free from this flaw. Even the leading Supreme Court case, Davis $v$. Beason, ${ }^{34}$ suggested that the purpose of such laws was to exclude ex-felons because of the way they might vote. If this is really the purpose of the laws, they must then fall within the ban on "fencing out" groups because they might vote differently or take over the government.

28. See Note, The Equal Protection Clause as a Limitation on the States' Power to Disenfranchise Those Convicted of a Crime, 21 Rutcers L. REv. 299, 309-10 (1967). This is a particularly plausible interpretation for state laws which are contained in the "penal" sections of their codes, e.g., Colo. Rev. Stat. AnN. $\$ 39-10-18$; Kan. Stat. ANN. $\$ 62.2252$ (1964); OHo Rev. CoDE ANN. $\$ \$ 2961.01-.02$ (Page 1954). See Singleton v. State, 38 Fla. 297, 302, 21 So. 21, 23 (I896); Eikin v. Commonwealth, $269 \mathrm{Ky}$. 6, 8, 106 S.W.2d 83, 84 (1937); In re Coppola, 155 Ohio St. 329, 335-36, 98 N.E.2d 807, 810-11 (1951) (dicta); In re Moskowitz, 329 Pa. 183, 186, 196 A. 498, 500 (1938); cf. Borino v. General Registrars, 86 Conn. 622, 86 A. 597 (1913).

29. See Green v. Board of Elections, 380 F.2d 445, 451 (2d Cir. 1967), cert. denied, 389 U.S. 1018 (1968).

30. Graham v. Richardson, 403 U.S. 365 (1971) (in awarding welfare benefits, a state has no valid interest in excluding aliens resident within the state); Shapiro v. Thompson, 394 U.S. 618 (1969) (in determining qualifications for welfare benefits, it is an impermissible purpose for a state to seek to keep indigents out of the state or to limit benefits and services to those who have "contributed" to the state through taxes); Reynolds v. Sims, 377 U.S. 533 (1964) (implication that a state does not have a valid interest in protecting the integrity of political subdivisions by drawing unequal election districts); Griffin v. School Bd., 377 U.S. 218 (1964) (a county may not close its schools for the purpose of encouraging segregation, because this is an impermissible purposc).

31. Dunn v. Blumstein, 405 U.S. 330 (1972). See also Kramer v. Union Free School Dist., 395 U.S. 621 (1969). The only exception to this rule is for elections in special districts, established to perform certain limited functions but not exercising any general governmental power, Salyer v. Tulare Basin Water Storage Dist., 410 U.S. 719 (1973). The Court there emphasized that such districts were exempt from the general Reynolds rule only because of their limited powers.

32. Cipriano v. City of Houma, 395 U.S. 210 (1969).

33. Carrington v, Rash, 380 U.S. 89, 95 (1965).

34. 131 U.S. 333 (1898). See cases cited note 39 infra; Note, supra note 13, at 854 . 
The ex-felon exclusion laws may be tainted with this impermissible purpose even if the stated purpose is to restrict the vote to those who are "qualified" or "knowledgeable." No state gives potential voters an objective test of knowledge or competence, ${ }^{35}$ a fact which suggests that the asserted goal of determining voter qualifications may be nothing more than a rationale for excluding those who might vote differently from the majority. ${ }^{36}$ When a state excludes children or the insane, it acts on the principle that such people are incapable of making a rational political choice because of their physical or mental condition. ${ }^{37}$ There is no evidence, however, that ex-felons are unable to act as rationally as others. ${ }^{38}$ The state in excluding them cannot be determining "qualifications" in the sense of knowledge of civic affairs (unless it is acting completely without a rational basis for its policy). Instead, there could only have been a determination that ex-felons are morally unfit to vote by reason of their bad character.

The idea of "moral unfitness" to vote can be interpreted in several different ways. First, it may simply be a restatement of the view that criminals should be excluded from the political process because of the way they might vote. ${ }^{39}$ The state might fear that the ex-felon

35. The closest states have ever come to such a test is through literacy tests, which the Court has held constitutional when not discriminatory, Gaston County v. United States, 395 U.S. 285 (1969); Lassiter v. Northampton County Bd. of Elections, 360 U.S. 45 (1959), but which are now banned in all elections by federal statute, 42 U.S.C. $\$ \S 1973(\mathrm{~b}), 1973 \mathrm{aa}(\mathrm{a})(1970)$, upheld in Oregon v. Mitchell, 400 U.S. 112 (1970).

36. See Dunn v. Blumstein, 405 U.S. 330, $354-59$ (1972).

37. See note 27 supra; cf. Oregon v. Mitchell, 400 U.S. 112, 242 (1970) (opinion of Brennan, White, and Marshall, JJ.). In determining where the line should be drawn in excluding children, legislatures must of necessity be given some discretion to make a rational judgment on when the "age of reason" begins. Obviously a one-year-old can be excluded because of age; equally obviously, a forty-year-old could not. Any line is bound to be arbitrary, because some of those deemed too young will be more intelligent and informed than some of those who are deemed old enough. At the same time, it would be impossible to devise an objective test of maturity and rationality for all citizens. The only way, therefore, to exclude the obviously immature is to draw the line at some specific age, and the courts can only require that there be a rational basis for the age chosen. In Oregon v. Mitchell, it is possible to read the Douglas opinion and the joint Brennan, White, and Marshall opinion as applying this sort of standard to the state twenty-one-year-old voting laws. See also Note, supra note 13, at $855 \mathrm{n} .78$ (suggesting that age qualifications can be distinguished because they are limited in time); cf. McDonald v. Board of Election Comm'rs, 394 U.S. 802 (1969).

38. Of course, to be considered a rational and intelligent voter, the ex-felon need not make his voting decisions entirely on the basis of a dispassionate evaluation of the issues and the public interest. It is generally accepted (especially by politicians campaigning for votes) that most voters act according to (at best) enlightened self-interest. If ordinary voters are allowed to "vote their pocketbooks" or respond to similar appeals, ex-felon voters should not be held to a higher standard of rationality.

39. Cf. Kronlund v. Honstein, 327 F. Supp. 71, 73 (N.D. Ga. 1971); In re Minner, 133 Kan. 789, 3 P.2d 473 (1931); Ratliff v. Beale, 74 Miss. 247, 266-67, 20 So. 865, 868 (1896); State ex rel. Barret v. Sartorius, 351 Mo. 1237, 124142, 175 S.W.2d 787, 788 (1943); State ex rel. Olson v. Langer, 65 N.D. 68, 86, 256 N.W. 377, 385 (1934). 
might cast his vote for purposes other citizens consider immorali.e., by voting for public policies with which they disagree. ${ }^{40}$ Judge Friendly has suggested ${ }^{41}$ that disenfranchisement is the consequence of the ex-felon permanently placing himself outside the social and political community by violating its "social contract." This is another view of the "moral unfitness" notion. An argument on this level of philosophical abstraction, however, is either circular or at best a legal conclusion: Ex-felon disenfranchisement is justified because of the violation of the "social contract" and the existence of the "social contract" is defined by the criminal laws. Moreover, the legitimacy of such a philosophical rationale may have been undermined to some extent by the cases denying a governmental power to withdraw citizenship without a person's consent. ${ }^{42}$

Finally, "moral unfitness" may simply mean that disenfranchisement of ex-felons is a punishment or a regulatory device designed to prevent future election law violations. If punishment is the principal purpose, there may be equal protection issues raised by the irrational distinctions made in determining which offenses cause disenfranchisement, ${ }^{43}$ but the most serious problems would arise from other constitutional prohibitions. ${ }^{44}$ The difficult equal protection question arises if the legislative purpose is defined as the prevention of election crimes, fraud, bribery, or related political

40. If a state is allowed to exclude ex-felons because they are morally unfit, what other people or groups could be excluded by the same rationale? A state might be able to require prospective voters to obtain character references from respected members of the community (since that would seem to be a more accurate way of isolating the immoral than exclusion of the broad class of ex-felons, many of whom might have reformed). Cf. Note, supra note 13 , at 854 . A state might be able to exclude members of organizations which it has good reason to believe advocate violence for political purposes (Communists, members of the Ku Klux Klan or the John Birch Society, Black Panthers). Indeed, Gilbert Green's "moral unfitness" to vote resulted from his conviction for being a Communist. See Green v. Board of Elections, 380 F.2d 445 (2d Cir. 1967), cert. denied, 389 U.S. 1048 (1968). See also Ratliff v. Beale, 74 Miss. 247, 20 So. 865 (1896) (covert racial discrimination).

It is hard to believe, however, that the courts would permit a disenfranchisement system with the purpose or the effect of removing a group of political dissenters from the election process. In fact, Otsuka v. Hite, 64 Cal. 2d 596, 414 P.2d 412, 51 Cal. Rptr. 284 (1966), in which the California Supreme Court drastically restricted the scope of the state disenfranchisement Iaw, see note 3 supra, was inspired in part by the legal and political difficulty of using the laws to disenfranchise convicted draft evaders during the Vietnam War. Cf. Trop v. Dulles, 356 U.S. 86 (1958).

41. Green v. Board of Elections, 380 F.2d 445, 451 (2d Cir. 1967), cert. denied, 389 U.S. 1048 (1968).

42. See Afroyim v. Rusk, 387 U.S. 253, 258 (1967); Trop v. Dulles, 356 U.S. 86, 93 (1958).

43. Cases such as Skinner v. Oklahoma, 316 U.S. 535 (1943), have invalidated discriminations which rested on a completely illogical distinction among offenses. See note 73 infra.

44. See generally pp. 593-601 infra. 
offenses. ${ }^{45}$ The rest of this discussion will focus on the validity under equal protection doctrine of disenfranchisement for this purpose. ${ }^{40}$

\author{
II
}

The California Supreme Court in Ramires correctly relied on the application of the strict scrutiny standard of review. ${ }^{47}$ Since Reynolds $v$. Sims ${ }^{48}$ strict scrutiny has been applied to almost every voting

45. This is the purpose which the California court found in Otsuka v. Hite, 64 Cal. 2d 596, 414 P.2d 412, 51 Cal. Rptr. 284 (1966), and rejected in Ramires.

46. In Fincher v. Scott, 352 F. Supp. 117 (M.D.N.C. 1972), aff'd mem., 411 U.S. 961 (1973), the district court held that equal protection does not apply to ex-felon voting rights because the second section of the Fourteenth Amendment allows a state to deny the franchise to a person for "participation in rebellion or other crime" without loss of congressional representation. See U.S. CoNST. amend. XIV, $\S 2$. This is not, however, a valid justification for refusing to examine ex-felon disenfranchisement under the equal protection clause of the first section of the Fourteenth Amendment; the fact that a state risks no specific penalties by excluding ex-felons is not a positive authorization of the practice if other constitutional provisions are violated by it; cf. Reynolds v. Sims, 377 U.S. 533, 589, 594 (1964) (rejection of Justice Harlan's position that $\$ 2$ of U.S. Const. amend. XIV, is the only section which deals with voting). But see Green v. Board of Elections, 380 F.2d 445, 452 (2d Cir.), cert. denied, 389 U.S. 1048 (1967). It would of course be different if the second section of the Fourteenth Amendment directly permitted states to exclude criminals or explicitly exempted ex-felon disenfranchisement from the other constitutional requirements, but the primary purpose and effect of that section was to prevent "the readmission of an increased number of southern representatives elected only by white secessionists ...."Van Alstyne, The Fourteenth Amendment, The "Right" to Vote, and the Understanding of the Thirty-Ninth Congress, 1965 Sup. CT. REv. 33, 57. See generally id. at 45-68; cf. Note, supra note 13, at $850-51$.

If the penalty section of the Fourteenth Amendment were allowed to override the equal protection clause of the first section, then one would have to admit that a state could exclude anyone it wished (except those specifically enfranchised by U.S. CoNsr. amends. XV, XIX, XXVI) for any reason, as long as it were willing to have its representation reduced. Surely the courts would not let a state disenfranchise, for example, 1000 leading opponents of the dominant political party and then say that the only remedy would be a "proportional" reduction in representation; $c f$. Dunn v. Blumstein, 405 U.S. 330 (1972).

Even an argument that ex-felon voting could be distinguished on the basis that cxfelon disenfranchisement would not require reduction of representation would not in. sulate disenfranchisement from the equal protection clatse. The second section of the Fourteenth Amendment might be read to allow a state to exclude those under 21 years of age from voting in both federal and state elections ("But when the right to vote at any election for the choice of electors for President ... is denied to any of the male inhabitants of such state, being twenty-one years of age . . .), yet the Supreme Court in Oregon v. Mitchell, 400 U.S. 112 (1970), permitted Congress to use certain of its powers (its article I power to regulate elections, or its enforcement powers under U.S. ConST. amend. XIV, § 5) to deny the states the right to exclude 18-year-olds from federal elections. Similarly, the Court, while upholding the states' right to disenfranchise those under 21, did not purport to rest its decision on $\$ 2$ of the Fourteenth Amendment. Rather, it found that the disenfranchisement did not violate $\$ 1$, as enforced under \$ 5. See Oregon v. Mitchell, supra at 125-26. The Court thus apparently allows specific guarantees or grants of powers contained elsewhere in the Constitution to override any implied permission to disenfranchise citizens which might be found in $\$ 2$ of the Fourteenth Amendment. Accord, Stephens v. Yeomans, 327 F. Supp. 1182 , $1185-87$ (D.N.J. 1970); cf. In re Griffiths, 93 S. Ct. 2851 (1973) (rejecting arguments made in dissent that equal protection does not apply to aliens because other sections of the Constitution make distinctions between aliens and citizens).

47. 9 Cal. 3d at 206, 507 P.2d at 1349, 107 Cal. Rptr. at 141 .

48. 377 U.S. 533 (1964). 
question reaching the Court. ${ }^{49}$ It applies, of course, to the postReynolds reapportionment cases..$^{50}$ In 1966 it was used to strike down exclusions for failure to pay poll taxes. ${ }^{51}$ In 1968 formation of parties was declared to be a fundamental right. ${ }^{52}$ Two 1969 cases, employing strict scrutiny, forbade exclusion of nonproperty owners from bond issue votes ${ }^{53}$ and exclusion of nonproperty owners and nonparents from school elections. ${ }^{54}$ In 1972 strict scrutiny was extended to residency requirements for voting ${ }^{55}$ and to the right to run for office. ${ }^{56}$

49. See notes 50-57 infra. But cf. McDonald v. Board of Election, 394 U.S. 803 (1969) (strict scrutiny was not extended to a statute denying the right to receive absentec ballots to certain people, including those in prison, because the absentee ballot system was held to be a progressive reform, allowing piecemeal extension, and not a fundamental right). This restriction of strict scrutiny is not relevant here, since actually denying the right to vote is very different from a denial of benefits of a system designed to make voting casier and more convenient; cf. Goosby v. Osser, 409 U.S. 512 (1973) (stggesting that MCDonald does not extend to an outright denial of the right to vote). IICDonald suggests that a voter registration law which made registration casier for some people but more difficult for felons or ex-felons might be subject only to the traditional rationality test. Here, however, ex-felons are denied the right to register and vote under any circumstances or conditions, a situation which does not appear to come under the McDonald exception. The Supreme Court this term is also revicwing a New York decision, O'Brien v. Skinner, 31 N.Y.2d 317, 291 N.E.2d 134, 338 N.Y.S.2d 890 (1972), prob. juris. noted, 411 U.S. 963 (1973), which may limit McDonald.

The Court in Oregon v. Mitchell, 400 U.S. 112 (1970), also refused to apply strict scrutiny to a voting case in its holding that state voting age requirements were valid. In that case, however, there was no majority or even plurality holding. Four justices would have applied a strict scrutiny equal protection test, and four others would have held equal protection either inapplicable in voter qualification cases or satisfied by a showing that the law made no suspect classifications. The key opinion by Justice Black rested on the argument that the states have the power to set voter qualifications except when specifically barred by the Fourteenth Amendment (as with racial exclusions). The objective of excluding children is a permissible state purpose, see Kronlund v. Honstein, 327 F. Supp. 71,73 (N.D. Ga. 1971), and the only question is which legislative body will have the authority to engage in the necessary line-drawing. Justice Black's opinion merely holds that the states retain that power in state elections, while Congress has the power over congressional elections. None of the opinions in Oregon v. Mitchell, however, can be read as authorizing state action in the voter qualification area for an impermissible state purpose.

50. Many of the post-Reynolds reapportionment cases have ordered relief without any consideration of an equal protection standard, merely citing Reynolds. See, e.g., Hadley v. Junior College Dist., 397 U.S. 50 (1970); Kirkpatrick v. Preisler, 394 U.S. 526 (1969). In such cases one can assume that the basic Reynolds test is still relevant. Recent cases refusing to extend or apply Reynolds have not challenged the reasoning in that case, but have held that it did not apply because the exclusionary practices challenged did not in fact cause any infringement of the right to vote, Salyer $v$. Tulare Basin Water Storage Dist., 410 U.S. 719 (1973); Whitcomb v. Chavis, 403 U.S. 124 (1971). The Salyer case involved a special election in a water district, and the Court stressed the difference between this and a general election. Whitcomb was a challenge to a multi-member clection district system. No one was denied the right to cast a ballot and each vote had an equal weight; neither case suggests that strict scrutiny does not apply where a state takes away or dilutes the right to vote in an clection for general political officials.

51. Harper v. Virginia Bd. of Elections, 383 U.S. 663 (1966).

52. Williams v. Rhodes, 393 U.S. 23 (1968). The Court held that the right to form political parties was guaranteed under the First Amendment, which made it a fundamental right for the purposes of the equal protection clause.

53. Cipriano v. City of Houma, 395 U.S. 701 (1969) (bond referendum).

54. Kramer v. Union Free School Dist., 395 U.S. 621 (1969) (school district election).

55. Dunn v. Blumstein, 405 U.S. 330 (1972) (residence requirements).

56. Bullock v. Carter, 405 U.S. 134 (1972) (the right to run for political office). 
The state may have different interests in excluding ex-felons than it has in excluding nonresidents or those with no economic or personal stake in the election, ${ }^{57}$ but the right to vote is just as fundamental to the potential voter in each case. There is no reason, therefore, for strict scrutiny to stop short of ex-felon disenfranchisement.

If the strict scrutiny standard is applied, the California statute must almost certainly fall. In the first place, as the Ramires court argued, enforcement of the election laws is presumably sufficient to detect and deter whatever election fraud exists. ${ }^{58}$ (At least no evidence has been put forward which suggests the opposite.) The fact that the 20 states without full disenfranchisement do not have significantly more election fraud suggests that ex-felon exclusion laws are unnecessary for that purpose..$^{59}$ Also, a state would have great difficulty proving that all of the ex-felons caught in the sweeping terms of its statute must be disenfranchised to protect the ballot, when, for example, excluding only election law offenders might be a less drastic means of preventing fraud. ${ }^{60}$

Even if strict scrutiny is not applied to this case, it is very possible that the California and other state statutes are not even rationally related to statutory purposes which the "old" equal protection requires. ${ }^{61}$ For example, there is absolutely no evidence to either prove or disprove the basic assumption which underlies the policy of excluding ex-felons to protect the election system: that exfelons are more likely than others to violate election laws or otherwise abuse the ballot. Since election crimes are atypical offenses, there

57. But cf. discussion of cases limiting strict scrutiny, notes $48-50$ supra.

58. Ramires v. Brown, 9 Cal. 3d 199, 214, 507 P.2d 1345, 1355, 107 Cal. Rptr. 137, 147 (1973). Accord, Dunn v. Blumstein, 405 U.S. 330,353 (1972); cases cited id. at n.24; cf. Dillenberg v. Kramer, 469 F.2d 1222, 1225 (9th Cir. 1972).

59. DuFresne \& DuFresne, The Case for Allowing Convicted Mafiosi to Iole for Judges, 19 DePaul L. REv. 112, 126-27 (1969).

60. Excluding election law offenders, under a strict scrutiny test, might be proven necessary to prevent further crime, in which case it would be permissible if the state had no less drastic means than that available and if the statute met minimum rationality standards.

There is a certain lack of clarity in the whole concept of disenfranchisement to prevent election crimes. Some election crimes (such as vote selling) require the violator to be a qualified voter, e.g., CaL. Elecrions CODE \$ 12000 (West Supp. 1973). Other activities which create opportunities for fraud (such as poll-watching) may also require that the person be entitled to vote himself, e.g., ConN. GEN. STAT. REv. \$ 9-235 (1963). In such cases, there is a direct relationship between disenfranchisement and prevention of crime. Some other crimes, however, such as bribery, e.g., Cal. Elecrions CoDE $\$ 12003$ (West Supp. 1973), do not require that the offender be a voter. Only in the former case, where, by denying a potential criminal the instrumentality with which he can commit a crime, cf. 18 U.S.C. $\$ \$ 922(\mathrm{~d})(\mathrm{l}),(\mathrm{g})(\mathrm{l})$ (h)(l) (1970) (unlawful for ex-felon to receive or own firearms), the state attempts to prevent recurrence of crime, would exclusion of election law offenders be permissible.

61. See Note, Legislative Purpose, Rationality, and Equal Protection, 82 YALE L.J. 123 (1972). 
is no logical basis for connecting ordinary crimes and election offenses. Most election crimes (multiple voting, tampering with ballots or voting machinery, bribery) ${ }^{62}$ require a high degree of interest and involvement in political affairs, and voting studies tend to suggest that the poor and less educated groups, those groups including, of course, a disproportionate number of criminals, are more likely to be politically apathetic. ${ }^{63}$ If this is true, then ex-felons might be less likely to commit election crimes than other people. ${ }^{64}$ Ex-felon disenfranchisement to protect the ballot, therefore, is an irrational classification which fails to advance the purposes for which it was enacted, and it consequently does not satisfy even the most permissive equal protection standard.65

The fact that the class singled out and treated differently consists of ex-felons does not permit disregard of the rationality rule of the equal protection clause. Discriminations against convicts and ex-felons must undergo the same equal protection examination as any other kind of classification, even when equal protection requirements are held to be satisfied because of rationality or a compelling state interest. ${ }^{\circ 6}$ The Supreme Court has invalidated for lack of rationality laws denying prisoners sentenced or awaiting trial the protections of the civil commitment process, ${ }^{67}$ and laws allowing the state to enter judgments against indigent criminal defendants for recovery of defense costs without giving them the protections (such as freedom from

62. E.g., Cal. Elections Code $\$ \S 220,12000-08,14403,29130-35,29430$ (West Supp. 1973).

63. A. Campbell, The American Voter 479-81 (1960).

64. It is perhaps too glib an illustration, but it appears that violators of election laws today are more likely to resemble the "Watergate" participants (or local machine bosses) in their socioeconomic backgrounds.

65. It would appear that exclusion of those convicted of election crimes, bribery, or election fraud could perhaps be validly excluded under the equal protection rationality test. Such people, having once committed such offenses, can be connected with election crimes much more directly than ordinary felons, particularly if commission of the election offense involved an ability to vote; $c f$. note 60 supra. It may or may not be true that a person who has committed an election crime is more likely to do so again than is another person, but the courts would probably not say that it is irrational for a legislature to conclude that he is. This is exactly what the California Supreme Court held in Otsuka v. Hite, 64 Cal. 2d 596, 414 P.2d 412, 51 Cal. Rptr. 284 (1966).

66. There would appear, however, to be an exception to this rule for certain losses of liberty which are directly connected with the conditions of imprisonment and parole. See, e.g., Berrigan v. Siegler, 358 F. Supp. 130 (D.D.C. 1973) (a parolee can be denied a passport without an infringement of First Amendment rights, because the liberty of a parolee is not unlimited).

67. Baxstrom v. Herold, 383 U.S. 107 (1966), held that prisoners about to be civilly committed cannot be denied the hearing and trial which others receive, even though insane persons with criminal propensities may require different treatment. Jackson v. Indiana, 406 U.S. 715 (1972), citing Baxistrom, extended this protection to those awaiting trial. See also Humphrey v. Cady, 405 U.S. 504 (1972), citing and extending Baxstrom. 
garnishment) that other judgment debtors receive. ${ }^{68}$ The implication of these cases is that discrimination against the class of exfelons must be directly connected with the sentences imposed by the courts. Such a direct connection between the terms of a sentence and voting by the ex-felon whose term of imprisonment and parole has ended seems totally lacking. ${ }^{60}$

Within the class of "criminals" itself the equal protection clause requires the categories to be drawn carefully and rationally, as with any other kind of legislation. It is not sufficient that a classification include some offenders and exclude others irrationally. In Skinner v. Oklahoma ${ }^{70}$ the Supreme Court invalidated a law allowing sterilization of certain felons because it drew an irrational distinction between those convicted of "larceny" and those convicted of "embezzlement." The Court has also invalidated laws providing free trial transcripts only for indigent "felons," 71 and laws which in requiring repayment of in forma pauperis trial records discriminate irrationally between those sent to jail and those merely fined.72

If every ex-felon disenfranchisement law were subjected to this form of analysis, many might be unconstitutional. Certainly a state which disenfranchises those convicted of theft of a certain object but not those convicted of theft of another object of equal value violates the Skinner v. Oklahoma standard..$^{33}$

68. James v. Strange, 407 U.S. 128 (1972), found no rational basis for denying those bound to pay back defense costs the protections other judgment debtors receive.

69. If equal protection of the laws is denied the ex-felon who has lesser rights against judgment creditors, see id., it must certainly be denied to the ex-felon cxcluded from the franchise, especially since voting has been held to be a fundamental right (unlike protection against creditors). The only Supreme Court decision suggesting the opposite is McDonald v. Board of Election, 394 U.S. 803 (1969), which held that prisoners could arbitrarily be denied absentee ballots, but the court there emphasized that reform legisiation which gave a special privilege to some people would not have to meet the same equal protection tests as a law interfering with people's rights. See note 48 supra.

70. 316 U.S. 535 (1942).

71. Mayer v. City of Chicago, 404 U.S. 189 (1971), held that a state cannot provide free transcripts only for poor "felons" and not poor misdemeanants "(the opinion, however, focused more on the discrimination between rich and poor persons accused of misdemeanors).

72. Rinaldi v. Yeager, 384 U.S. 305 (1966), held unreasonable a law allowing collection of defense costs from the prison pay of convicts, with no attempts to collect from those merely fined.

73. Texas, for example, disenfranchises a person for the felony of stealing any quantity of "wool, mohair or edible meat" but not for the misdemcanors of stealing larger quantities of, say, cotton or cdible vegetables (the theft of which is not auto. matically a felony). Tex. PENal CoDE ANN. \$ 1426(c) (1953). See also the odd distinctions in Arizona, California, New Jersey, Mississippi, and Washington law discussed in Dillenberg v. Kramer, 469 F.2d 1222, 1225 n.6 (9th Cir. 1972) (e.g., bribing a witness causes disenfranchisement, but influencing a juror does not); Stephens v. Yeamans, $327 \mathrm{~F}$. Supp. 1182, 1188 (D.N.J. 1970); Otsuka v. Hite, 64 Cal. 2d 596, 605, 414 P.2d 412, 418, 51 Cal. Rptr. 284, 290 (1966); Ratliff v. Beale, 74 Miss. 247, 266-67, 20 So. 865, 868 (1896); Vanderbilt Projecr, supra note 1 , at 1173 n.84. See generally id. at 952-66.

Indeed, the arbitrâry line between "felons" and "non-felons" seems to have raised as 
There may, in addition, be serious "substantive" due process objections to a regulatory disenfranchisement law. The Court has said that the due process clause requires that a law interfering with personal rights be "in the context of the particular circumstances which gave rise to the legislation, a reasonable means for advancing a legitimate state aim."74 This is almost identical to the "old" equal protection test, except that it is not a classification which is important, but the treatment of each individual's rights. This due process test was used to sustain a law excluding ex-felons from waterfront union positions, but the Court stressed that "New York was not guessing or indulging in airy presumptions that convicted felons constituted a deleterious influence on the waterfront. It was acting on impressive if mortifying evidence ...." T5 The Court also emphasized the seriousness of the waterfront situation. Applying this standard to ex-felon voting laws, there appears to be no such clear and immediate danger from ex-felon activities as there was in that case. The connection between ex-felon voting and election fraud is not sufficiently direct to meet this rationality test and avoid the charge of acting on "airy presumptions." 76

The question of legislative presumptions raises another serious due process question. It is clear that in enacting the ex-felon voting laws the states must have acted in part on the assumption that exfelons were more likely than others to commit violations of the

many equal protection problems in judges' minds as the general equal protection issue discussed in the text (i.e., whether any class of ex-criminals is unqualified to vote). See Dillenberg v. Kramer, supra at 1225; Stephens v. Yeomans, supra at 1188; Otsuka v. Hite, supra at 605; cf. Vlandis v. Kline, 412 U.S. $441,446.49$ (1973) (White, J., concurring).

74. DeVeau v. Braisted, 363 U.S. 144, 157 (1960). Another case decided the same year, Flemming v. Nestor, 363 U.S. $603(1960)$, seemed to set up a less exacting test for statutes involving economic or social welfare regulation: "Particularly when we deal with a withholding of a non-contractual benefit under a social welfare program such as this, we must recognize that the Due Process Clause can be thought to interpose a bar only if the statute manifests a patently arbitrary classification, utterly lacking in rational justification." Id. at 611 . The Flemming case involved a United States law denying Social Security benefits to aliens deported because of their membership in the Communist Party. The Court in applying its own standard stressed the economic and fiscal decisions which Congress had to make in determining who was to receive government benefits and emphasized that the aliens had no right to the benefits they were denied. The DeVeau standard is clearly more appropriate here, because voting is a right, not a privilege, and because voting does not involve a "social welfare program." See also Garner v. Board of Public Works, 341 U.S. 716, 722 (1951) (a comparable due process claim rejected without enunciating a standard).

75. DeVeau v. Braisted, 363 U.S. 144, 159 (1960).

76. See pp. 590.91 supra. There would appear to be no reason for thinking that if ex-felon disenfranchisement cannot satisfy equal protection rationality, it can satisfy due process rationality. 
election laws. ${ }^{77}$ Even if this assumption were sufficiently justified to meet the rationality test under the equal protection clause, ${ }^{78}$ recent authority suggests that a state is barred by the due process clause of the Fourteenth Amendment from making irrebutable presumptions about a person's qualities or future behavior. Stanley $v$. Illinois in 1972 held that in awarding custody of children a state could not presume unwed fathers unfit to be guardians of their illegitimate children without allowing them an opportunity to rebut the presumption. ${ }^{79}$ Similarly, in Dunn v. Blumstein ${ }^{80}$ the Court held that a state, for the purpose of determining residency for voting, could not presume that recent arrivals did not intend to become permanent residents.

There appears to be no reason why the same rule should not apply to ex-felon disenfranchisement. These cases involve a presumption as to future conduct or moral character, based on previous behavior. ${ }^{\$ 1}$ In all cases the presumption is irrebutable: The unwed father in Stanley $v$. Illinois could not present evidence about abilities or virtues as a guardian; the recently arrived resident could not present evidence about his intention to remain in the state; the ex-felon cannot show that he has reformed and is now a virtuous citizen capable of making an intelligent and informed choice on political questions.

The prohibition on "conclusive presumptions," while technically a due process doctrine, appears to be another branch of equal pro-

77. "The presumption is that one rendered infamous by conviction of felony . . is unfit to exercise the privilege of suffrage." Washington v. State, 75 Ala. 582, 585, 51 Am. R. 479,481 (1884).

78. No standard has yet been enunciated for determining the rationality of civil presumptions. The tests set up for criminal presumptions might shed some light on the question. Tot v. United States, 319 U.S. 463 (1943), set up a simple rationality requirement which was interpreted in Leary v. United States, 395 U.S. 6 (1969), to mean that the presumption must more likely than not be true in each case. See also United States v. Romano, 382 U.S. 136 (1965); United States v. Gainey, 380 U.S. 63 (1965). While the same strict standard should not be applied to civil cases as is applied to criminal cases (where guilt beyond a reasonable doubt must be shown), it is reasonable to conclude that civil presumptions should show some degree of rationality, if not as great as that required in Leary $v$. United States. If the presumption against ex-felons is not apparently rational enough to satisfy equal protection or due process requirements, it should not be sufficient here.

79. Stanley v. Illinois, 405 U.S. 654 (1972). See also Bell v. Burson, 402 U.S. 535 (197i) (due process clause bars state from requiring uninsured motorists involved in accidents to post bonds without hearing on probability of adverse judgment, because state is assuming their probable liability)

80. 405 U.S. 330, 349-5I (1972); cf. Carrington v. Rash, 380 U.S. 89, 95-96 (1965). A conclusive presumption against residency was struck down only last term in Vlandis v. Kline, 412 U.S. 441 (1973).

81. In siring an illegitimate child, plaintiff in Stanley may have violated the state fornication law. ILL. ANN. STAT. ch. 38, $\$ 11-81$ (Smith-Hurd 1973) (fine or imprisonment if fornication is "open and notorious"). 
tection doctrine. After all, every legislative classification subject to equal protection scrutiny involves a "conclusive presumption" as to some characteristic of the class in relation to the permissible purpose of the law. \$2 The distinction of "conclusive presumption" doctrine is its "passive virtue." 83 Instead of requiring the invalidation of a classification because it is not rational in relation to its purpose, the usual result of successful equal protection challenges, "conclusive presumption" doctrine only requires that the class members be given an individual opportunity to rebut the legislature's presumption as to their characteristics. The availability of this opportunity requires the legislature to define with precision the specific characteristics to which disenfranchisement attaches and how a class member may rebut the classification. ${ }^{84}$ This seemingly successful meld of equal protection and "procedural" due process ${ }^{85}$ thus reduces the scope of judicial intervention in legislative classifications and at the same time forces the legislature to reconsider the bases of its presumption as to the characteristics of the class under scrutiny. This approach to

82. See generally Tussman \& tenBroek, The Equal Protection of the Laws, 37 CALIF. L. Rev. 341 (1949). As was stated in F.S. Royster Guano Co. v. Virginia, 253 U.S. 412, 415 (1920), a legislative classification "must be reasonable, not arbitrary, and must rest upon some ground of difference having a fair and substantial relation to the object of the legislation, so that all persons similarly circumstanced shall be treated alike." The "conclusive presumption" in all equal protection litigation is that members of the legislatively determined class are all "similarly circumstanced" in relation to the purpose of the law. The gist of the normal equal protection complaint thus is that the legislatively determined class is imprecise, i.e., "under-inclusive" or "over-inclusive," and, therefore, the legislative presumption that individuals are "similarly circumstanced" is not correct.

Generally courts will defer to the legislative judgment on this issue and that is known today as "old" cqual protection, see Railway Express Agency v. New York, 336 U.S. 106 (1949); note 6I supra. In some areas the Court has been unwilling to defer to the legislative judgment that some people fall into a particular class, i.e., the Court finds there are "more precise tests" to separate those covered by the purpose of the law and those who are not. Dunn v. Blumstein, 405 U.S. 330, 349 (1972), citing Carrington v. Rash, 380 U.S. 89 , 95 (1965). To be sure, certain "substantive right" notions have been imported into equal protection law, thus defining certain "impermissible" legislative purposes and by-passing in large part the issue of the precision of the classification. See generally Karst \& Horowitz, Reitman v. Mulkey: A Telophase of Substantive Equal Protection, 1967 Sur. CT. REv. 39, 57.

83. The phrase is Professor Bickel's. See Bickel, Foreword: The Passive Virtues, 75 HARv. L. REv. 40 (1961); cf. Schneider v. Smith, 390 U.S. 17 (1968); Kent v. Dulles, 357 U.S. I16 (1958); Bickel \& Wellington, Legislative Purpose and the Judicial Process: The Lincoln Mills Case, 71 Harv. L. REv. 1 (1957). See also United States v. International Union, UAW, 352 U.S. 567, $590-93$ (1957).

84. This was the mandate in Vlandis v. Kline, 412 U.S. $441,452-54$ (1973). See note 87 infra. See also Stanley v. Illinois, 405 U.S. 645 (1972) (ordering a hearing to replace conclusive presumption); Bell v. Burson, 402 U.S. 535, 543 (1971) (ordering compliance with hearing requirement by any means the state chooses). It has been argued that the "conclusive presumption" doctrine remedy-individual determination of status in relation to a legislative purpose-is impractical in the ex-felon disenfranchisement situation. See Note, supra note 13, at 855, citing Otsuka v. Hite, 64 Cal. 2d 596, 615-16, 414 P.2d 412, 425-26, 51 Cal. Rptr. 284, 297-98 (1966) (Burke, J., dissenting).

85. Cf. Boddie v. Connecticut, 401 U.S. 371 (1971). 
the problem of ex-felon disenfranchisement may be particularly useful since disenfranchisement, as with other disabilities attaching to ex-felons, had its "origin in the fogs and fictions of feudal jurisprudence and doubtlessly has been brought forward into modern statutes without fully realizing either the effect of its literal significance or the extent of its infringement upon the spirit of our system of government."s6 The Supreme Court in upholding Ramires on this ground would be less engaged in definitive decisionmaking than in "remanding" the issue to state legislatures for a modern reconsideration of what ex-felon disenfranchisement is designed to accomplish and how that end can be more efficiently and fairly effectuated. ${ }^{\mathrm{st}}$ To be sure, the core equal protection problem would remain but it possibly would never be reached.

In fact, it is very possible that the due process clause prevents a state from taking away the right to vote solely by legislative and administrative action, without an opportunity for a hearing:ss The right to a hearing has in recent years been extended to many different kinds of criminal and civil proceedings, often involving a potential loss of rights which is far less serious than disenfranchise-

86. Byers v. Sun Savings Bank, 41 Okla. 728, 731, 139 P. 948, 949 (1914). See Dillenberg v. Kramer, 469 F.2d 1222, 1224, 1226 (9th Cir. 1972); Stephens v. Ycoman, 327 F. Supp. 1182, $1187-88$ (D.N.J. 1970); Inderson v. Baker, 23 Md. 531 (1865); l'RESIDEN1's ComM'N

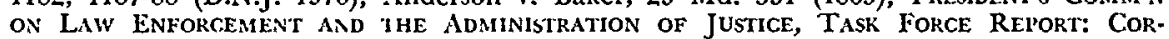
kLCIIONS 88 (1967); Note, supra notc 13, at $852-53$ n.62. See generally V.NDERbiLT ProJeCI, supra note 1 , at $941-52$.

87. Cf. Vlandis v. Klinc, 412 U.S. 441, 452-54 (1973). As discussed at pp. 584-85 supra, the purpose of modern disenfranchisement laws is virtually impossible to determine. The reconsideration facilitated by use of conclusive presumption doctrine would enable a legislature to authoritatively determine the purpose of ex-felon disenfranchisement in light of modern equal protection case law on "impermissible" purposes. See p. 585 supra. It also would give the legislature an opportunity to explore "reasonable alternative means," Vlandis v. Kline, 412 U.S. 441,452 (I973), for ascertaining which persons should be found incompetent to vote in light of the determined purpose. Finally, legislative reconsideration should include re-examination of which criminals should be classified as a threat to the electoral system. See note 73 supra; cf. Vlandis v. Kline, supra at $456-59$ (White, J., concurring).

88. The subjects to be taken up at a hearing might vary from state to statc de. pending on the reasons for disenfranchiscment. Where all who are convicted of certain enumerated offenses are disenfranchised, the only isste at a hearing might be the validity of the conviction, with the original judicial finding of guilt binding on civil procecdings. On the other hand, in a state like California which takes away the right to vote only for crimes indicating that the offender would be a threat to the clection system, the whole question of moral fitness or the propensity to commit election crimes might have to be raised at such a hearing.

Some states, see note 16 supra, have liberalized the pardon process by giving the courts or administrative boards the power to hear appeals for the return of civil and political rights. This might satisfy the hearing requirements, but only if the court or board must hold hearings on all petitions instead of acting on its discretion, only if it considers all issues involved in disenfranchisement at the hearing, and only if the other procedural requirements for a fair hearing are met; cf. Groppi v. Leslie, 401 U.S. 496 (1972); Cole v. Arkansas, 333 U.S. 196 (1948). See generally VANDERBiLt ProJECr, supra note 1, at 1197-1208. 
ment. ${ }^{80}$ If disenfranchisement is regarded as punitive,, 90 the cases requiring hearings before revoking parole would seem to be controlling: ${ }^{.1}$ Disenfranchisement as a punishment follows conviction in court, but it is not part of the original judge-imposed sentence.92 It is instead an administratively imposed sanction (like parole revocation) which follows imprisonment and may be based on different considerations than the original sentence. ${ }^{93}$ As long as different standards are involved or an additional determination of fact is required in disenfranchisement, it cannot be regarded as part of a "mandatory sentence" automatically attached to conviction by a court. ${ }^{94}$

If the purpose of the laws is regulatory, not punitive, the need for a hearing is even greater. Since a sentencing court is concerned only with applying the criminal law, it could not be argued that the defendant had a hearing on disenfranchisement through the original trial. ${ }^{95}$ Hearings are now required before deprivation of a wide range of rights or benefits. ${ }^{96}$ There is no logical reason for requiring a hearing before cutting off a person's welfare payments or denying him admission to the bar, but not before removing his voting rights. ${ }^{97}$

89. Gagnon v. Scarpelli, 411 U.S. 778 (1973) (hearings required for suspension of probation); Morrissey v. Brewer, 408 U.S. 471 (1972) (hearings required for parole revocation); Stanley v. Illinois, 405 U.S. 654 (1972) (unwed father cannot be denied curtody of his children without a hearing on fitness); Goldberg v. Kelly, 397 U.S. 254 (1970) (hearing required before welfare benefits are cut off); Sniadach v. Family Finance Corp., 395 U.S. 337 (I969) (no garnishment of wages may be ordered without hearings); In re Gault, 387 U.S. I (I967) (hearings in juvenile courts must be conducted in accord with all constitutional due process guarantees); Willner v. Committec on Character \& Fitness, 373 U.S. 96 (1963) (a person cannot be denied admission to the bar without a hearing).

90. See p. 585 supra.

91. Note, supra note 13 , at $860-61$.

92. If it were part of the original sentence, like a jail term or fine, the offender might be able to urge the judge to reconsider it or appeal it as inproperly handed down. Sec, e.g., FED. R. CRIM. P. 32, 35. In a practical sense, therefore, disenfranchisement procedures cannot be regarded as a kind of continuing enforcement of the original sentence. See note $9 \dot{x}$ infra.

93. In California there must be an administrative finding that the offender is a likely threat to the election process. Otsuka v. Hite, 64 Cal. 2d 596, 414 P.2d 412, 51 Cal. Rptr. 284 (1966); see note 3 supra.

94. It may be unconstitutional to impose disenfranchisement as a "mandatory sentence" in any event when the defendant does not have notice that it is part of the punishment he could receive; $c f$. Groppi v. Leslie, 404 U.S. 496 (1972); Cole v. Arkansas, 333 U.S. 196 (1948); Note, Restructuring the Plea Bargain, 82 Yale L.J. 286, 296 n.39 (1972). But cf. Franklin v. Commonwealth, 195 Ky. 737, 224 S.W. 299 (1922) (disenfranchisement permissible as mandatory sentence if included in the final judgment); In re Moskowitz, 329 Pa. 183, 196 A. 498 (1938). See also State v. Jones, 82 N.C. 685 (1880).

95. See Groppi v. Leslic, 404 U.S. 496 (1972); Cole v. Arkansas, 333 U.S. 196 (1948); cf. Sniadach v. Family Finance Corp., 395 U.S. 337 (1969).

96. See note 89 stipra.

97. See Goldberg v. Kelly, 397 U.S. 254 (1970); Willner v. Committec on Character \& Fitness, 373 U.S. 96 (1963). 
If disenfranchisement is imposed as a punishment (as distinguished from a regulatory measure), it may by its very nature be forbidden by the Eighth Amendment. ${ }^{98} \mathrm{~A}$ punishment need not involve death or torture to be cruel and unusual. ${ }^{99}$ The Supreme Court in Trop v. Dulles ${ }^{100}$ held the deprivation of citizenship to be an unconstitutional punishment, calling it a more "primitive" punishment than torture. ${ }^{101}$

While the Court emphasized the horrors of statelessness that the offender could suffer, the basic holding that deprivation of citizenship was cruel and unusual punishment is especially relevant to ex-felon disenfranchisement. Voting is in some sense the unique right of citizenship. Only citizens may vote, and only limited classes of citizens may be denied that right. Voting is not only a right "preservative of other basic civil and political rights," 102 but is also the ultimate act of citizenship, the one act which is both a symbol and a tangible demonstration of the citizen's full membership in the national community. ${ }^{103}$ When a state denies someone the right to vote, he can hardly be said to remain a full citizen. ${ }^{104} \mathrm{He}$ possesses a few impor-

98. Judge Friendly in Green v. Board of Elections, 380 F.2d 445, 450 (2d Cir. 1967), cert. denied, 389 U.S. 1048 (1968), held that ex-felon disenfranchisement presented no Eighth Amendment problems. This holding rested on two grounds: that loss of personal rights is not punitive and that it would not have been considered cruel and unusual in the eighteenth century. The first argument is inconsistent with Cummings: v. Missouri, 71 U.S. (4 Wall.) 277 (1866); Ex parte Garland, 71 U.S. (4 Wall.) 333 (1866). The second argument seems inconsistent with Furman v. Georgia, 408 U.S. 238 (1972).

99. "[I]t must have come to them [the framers of the Constitution] that there could be exercises of cruelty by laws other than those which inflicted bodily pain or mutilation." Weems v. United States, 217 U.S. 349, 372 (1910); cf. Robinson v. California, 370 U.S. 660 (1962); Trop v. Dulles, 356 U.S. 86 (1958). See generally VANDERuILT ProJect, supra note 1 , at 1195-98; Note, supra note 13 , at 858-60.

100. 356 U.S. $86(1958)$.

101. Id. at 101 .

102. Reynolds v. Sims, 377 U.S. 533, 561 (1964). Reynolds and other voting cases, e.g., United States v. Classic, 313 U.S. 299 (1941), make it clear that the right to vote, whether regarded as a national right or a right derived from the states, is strongly protected by the Constitution.

103. But representative government is in essence self-government through the medium of elected representatives of the people, and each and every citizen has an inalienable right to full and effective participation in the political processes of his state's legislative bodies. Most citizens can achieve this participation only as qualified voters through the election of legislators to represent them. Full and effective participation by all citizens in state government requires, therefore, that each citizen have an equally effective voice in the election of members of his state legislature.

Reynolds v. Sims, 377 U.S. 533, 562 (1964).

104. Dictum in Trop v. Dulles, 356 U.S. 86, 96-97 (1958), implies a distinction between citizenship and voting by using ex-felon disenfranchisement as an illustration of a valid exercise of state power, as contrasted with deprivation of citizenship. This is only dictum, however, and the only authority cited are the no longer acceptable cases of Davis v. Beason, 133 U.S. 333 (1898), and Murphy v. Ramsey, 114 U.S. 15 
tant rights, ${ }^{105}$ but the most significant aspect of his citizenship is gone and he is left only with the title of "citizen," now of comparatively slight value. A disenfranchised citizen more closely resembles a resident alien, protected by the Constitution but excluded from full participation in democratic political life. It follows from this that loss of voting rights should be treated as virtually equivalent to loss of citizenship, and it has been held that no one may be deprived of his citizenship against his will. ${ }^{106}$ The right to vote, therefore, may be too sacrosanct to be infringed by laws seeking to prevent election fraud.

Even if the general policy of ex-felon disenfranchisement were upheld against this line of attack, there may be problems arising from the way certain states determine what offenses cause loss of rights. The Court has said that a punishment may be cruel and unusual if it is excessive or disproportionate to the seriousness of the offense. ${ }^{107}$ In

(1885); sce note 9 supra. On the other hand, the Court in Trop cites a dialoguc in the congressional debates in which an immigration official conceded that there was only a "technical difference" between a felon's loss of the "rights" of citizenship and the loss of citizenship itsclf. 356 U.S. at 89 n.4. Moreover, it appears that sometimes a state view's disenfranchisement as part of a loss of citizenship rights. See, e.g., N.Y. ELECIIONS CODE $\$ 152$ (McKinney Supp. 1972). This would be particularly true where cx-felon disenfranchisement is connected with so-called "civil death" statutes. See VaNblruile l'roJkC1, supra note 1 , at $942-52$; $c f$. p. 587 supra. If all rights of citizenship are lost, however, in what sense does the offender remain a citizen? A New York Attorney General's opinion at one time held that a felon actually did lose his citizenship, but this was later reversed, 1925 OP. Arr'y GEN. 135, rev'd, 1943 OP. ATI'y GeN. 218.

Apparently "citizenship-like" challenges failed in the two instances in which they were asserted, see Ray v. Pennsylvania, 263 F. Supp. 630 (W.D. Pa. 1967); l'cople v. Stephano, 64 Ill. 2d 389, 212 N.E.2d 357 (1965), cert. denied, 385 U.S. 989 (1966). Sce VANDERILT PROJECT, supra note 1 , at $1174-75$, for a criticism of those decisions. See also DuFresne \& DuFresne, supra note 59 , at $119-20,130-31$.

105. A citizen has the right to protection by the United States government when he is abroad and cannot be deported for any reason; cf. l'erez v. Brownell, 356 U.S. $44,64-65(1958)$. With the application of the suspect classification to resident aliens in equal protection cases, however, Graham v. Richardson, 403 U.S. 365 (1971), there are practically no cases where important government rights, protections, or benefits can be denied to aliens. This means that more and more, an alien while in this country can do evcrything a citizen may except vote.

106. Sce Afroyin v. Rusk, 387 U.S. 253, 258 (1967) ("[W]c hold that the Fourteenth Amendment was designed to, and does protect every citizen of this Nation against a congressional forcible destruction of his citizenship, whatever his creed, color, or race. Our holding does not more than give to this citizen that which is his own, a constitutional right to remain a citizen in a free country unless he voluntarily relinquishes that citizenship."); Trop v. Dulles, 356 U.S. 86, 93 (1958) ("As long as a person does not voluntarily renounce or abandon his citizenship . . . his fundamental right of citizenship is secure.").

107. Trop v. Dulles, 356 U.S. 86, 100 (1958); Weems v. United States, 217 U.S. 349, 365 (1910). This does not mean that sentences have to be uniform or anything close to it, Howard v. Fleming, 191 U.S. 126 (1903), but extreme disparity or excessiveness is not permitted; cf. note 19 supra; Note, supra note 13, at 860-63 (suggesting that disenfranchisement is an "unreasonable" punishment under standards for parole and probation conditions, citing Sobell v. Reed, 327 F. Supp. 1294, 1303 (S.D.N.Y. 1971); Hyland v. Procunier, 311 F. Supp. 749, 750 (N.D. Cal. 1970)). 
Weems v. United States, ${ }^{108}$ for example, the Court gave consideration to the fact that the heavy list of punishments was inflicted for the relatively "minor" offense of falsification of a single public document. Some states, however, impose disenfranchisement for even less heinous offenses, such as petty larceny of certain specified objects or private sexual offenses. ${ }^{109}$ The fact that disenfranchisement as a punishment is not proportionate to the seriousness of the offense, but is instead imposed on an "all or nothing" basis, might also raise problems. ${ }^{110}$ A carefully drawn statute which disenfranchised only for offenses which were clearly "serious" in nature, made no irrational distinctions among offenses, and was not overly broad in defining its categories would be acceptable under this narrower Eighth Amendment standard. The statutes involved in the current disenfranchisement cases do not appear to be of this quality. ${ }^{111}$

\section{Conclusion}

The constitutional challenge to ex-felon disenfranchisement will force courts to reconsider an ancient practice in light of modern notions of individual rights and social welfare. As Judge Hufstedler noted, ${ }^{112}$ such notions do change as the nature of society and one's view of the proper role of citizens therein change. Equal protection doctrine today reflects the uniquely important position voting has

108. 217 U.S. $349,381(1910)$ ?

109. See note 19 supra.

110. Cf. Weems v. United States, 217 U.S. at 365. ("In a sense the law in controversy seems to be independent of degrees. One may be an offender against it, though he gain nothing and injure nobody. It has, however, some human indulgenceit is not exactly Draconian in uniformity. Though it starts with a severe penalty, between that and the maximum penalty it yields something to extenuating circumstances.") The "all or nothing" disenfranchisement system appears to lack even the inadequate amount of concession to "extenuating circumstances" found in the Weems statute.

111. There may also be a possible analogy to the interpretation of the Eighth Amendment given in Robinson v. California, 370 U.S. 660 (1962). That case held that it was unconstitutional to punish a person for his "status" when he no longer has the ability to escape that status. (In the Robinson case, the law made it a crime to be a drug addict.) But cf. Powell v. Texas, 392 U.S. 514 (1968) (public drunkenness is not a "status").

The status of being a drug addict and the status of being an ex-felon are essentially similar. Both arise from an illegal act but thereafter are beyond the individual's control (in fact, a felon has less opportunity to escape his status by his own effortsexcluding the pardon possibility-than the addict). The major difference is that disenfranchisement is directly connected with the past conviction for a specific offense, and might be viewed as continuing punishment of that offense, rather than of the continuing status.

112. Dillenberg v. Kramer, 469 F.2d 1222, 1226 (9th Cir. 1972). 
assumed in recent years. It also reflects a reevaluation of the societal view of the "criminal" as a social outcast. These developments coalesce in the issue of ex-felon disenfranchisement.

Courts confronting these challenges would be wise not to view their role as antagonistic to that of the legislature or, indeed, the citizenry at large. Rather, they should help to begin the process of reevaluation by striking down the present California and Washington disenfranchisement laws. In the aftermath of such a decision state legislatures and their constituencies may be able to reformulate the scope of such laws in a manner consistent with modern views of democracy. 